\title{
Histone Acetylation and the Maintenance of Chromatin Compaction by Polycomb Repressive Complexes
}

\author{
R. Eskeland, ${ }^{1}$ E. Freyer,${ }^{1}$ M. Leeb,${ }^{2}$ A. Wutz,${ }^{2}$ And W.A. Bickmore ${ }^{1}$ \\ ${ }^{1} M R C$ Human Genetics Unit, Institute of Genetics and Molecular Medicine, University of Edinburgh, \\ Edinburgh EH4 2XU, Scotland, United Kingdom; ${ }^{2}$ The Wellcome Trust Centre for Stem Cell Research, \\ University of Cambridge, Cambridge CB2 1QN, United Kingdom \\ Correspondence: W.Bickmore@hgu.mrc.ac.uk
}

\begin{abstract}
Mechanisms controlling higher-order chromatin structure or chromatin compaction and linking this to gene regulation are poorly understood. Previously, we had shown that the PRC1 Polycomb repressive complex is required to maintain a compact chromatin state at Polycomb target loci in embryonic stem cells (ESCs) of the mouse and that this activity, together with the ability to repress target gene expression, is surprisingly independent of the histone ubiquitination activity of the Ring1B component of PRC1. Here we investigate and discuss the role of another histone modification - histone acetylation — in Polycomb function. We show that inhibition of histone deacetylases leads to some decompaction of Hox loci and suggest that histone deacetylation has a role in the pathway of PRC1-mediated chromatin compaction. We discuss whether PRC1 and histone hypoacetylation function together to establish a chromatin template at which stable nucleosomes act to antagonize transcriptional elongation.
\end{abstract}

In vitro, Polycomb proteins and complexes can compact nucleosome arrays (Francis et al. 2004; Margueron et al. 2008). In vivo, both principal Polycomb repressive complexes (PRC1 and PRC2) have been implicated in maintaining a compact chromatin structure at an imprinted gene cluster in trophoblast stem cells and trophectoderm (Terranova et al. 2008), and we have recently shown that the PRC1 component Ring1B, and likely PRC1 itself, is required to keep the murine Hox gene loci-well-known Polycomb targets - in a compact state in ESCs (Eskeland et al. 2010). In that system, we suggest that the primary function of the PRC2 complex (Ezh2/Suz12/Eed) is to trimethylate histone $\mathrm{H} 3$ at lysine 27 (H3K27me3) via the histone methyltransferase (HMTase) activity of Ezh2. This provides a binding platform for PRC1 (Boyer et al. 2006; $\mathrm{Ku}$ et al. 2008) via the affinity of the chromodomain of the Polycomb homologs for H3K27me3 (Kuzmichev et al. 2002; Wang et al. 2004b; Bernstein et al. 2006). Whereas methylation of $\mathrm{H} 3 \mathrm{~K} 79$ and $\mathrm{H} 4 \mathrm{~K} 20$ can affect the structure of the nucleosome and high-order chromatin structure $(\mathrm{Lu}$ et al. 2008), there is no evidence that $\mathrm{H} 3 \mathrm{~K} 27 \mathrm{me} 3$ per se can alter nucleosome interactions to change higher-order structure (Simon and Kingston 2009). Even a canonical PRC2 complex has little effect on nucleosome arrays in vitro, although a modified PRC2 complex that contains Ezh1 instead of Ezh2 does compact nucleosome arrays, despite the absence of robust HMTase activity by Ezh1 (Margueron et al. 2008).

\section{CHROMATIN COMPACTION AT HOX LOCI IN ESCS REQUIRES PRC1}

In ESCs, PRC2 is bound at, and mediates, H2K27 trimethylation at developmentally regulated genes, includ- ing Hox loci (Azuara et al. 2006; Bernstein et al. 2006; Boyer et al. 2006; Jorgensen et al. 2006; Lee et al. 2006; Stock et al. 2007; Endoh et al. 2008). H3K27me3 is lost from Hox loci during ESC differentiation, and concomitant with this, we have used fluorescence in situ hybridization (FISH) to show that the chromatin at Hox loci decompacts (Eskeland et al. 2010), recapitulating what is seen in the embryo proper, at sites of Hox gene activation (Chambeyron et al. 2005; Morey et al. 2007). We ascribed this chromatin decompaction to loss of the PRC1 complex, rather than PRC2 activity per se, because compaction is lost in ESCs mutant for the PCR1 component Ring1B, even though H3K27me3 still extensively decorates Hox loci in the mutant cells (Eskeland et al. 2010).

But how does the PRC1 complex compact chromatin at its target loci? Like PRC2, PRC1-like complexes also have histone-modifying activity. Ring1 A, and the Ring1B component that is in mammalian PRC1 as well as several other complexes, can ubiquitinate H2AK119 through their E3 ligase activities (de Napoles et al. 2004; Wang et al. 2004a). Monoubiquitination of histone H2A by the PRC1 complex depends on the interaction of Ring1B with another Ring-domain-containing component of PRC1 (Fig. 1A), either Bmi1 (Buchwald et al. 2006) or Mel18 (Elderkin et al. 2007).

In the absence of Ring1B (Ring $1 B^{-/}$), other PRC1 components are also lost, presumably by protein degradation, and levels of H2AK119 ubiquitination decrease (Leeb and Wutz 2007; Eskeland et al. 2010). H2A ubiquitination (Fig. 1C), the stability of the PRC1 complex (Fig. 1D), and also chromatin compaction (Fig. 1E) are all restored when wild-type Ring1B is reintroduced into Ring $1 B^{-/-}$ ESCs. This confirms that chromatin decompaction is likely a direct result of loss of PRC1. 


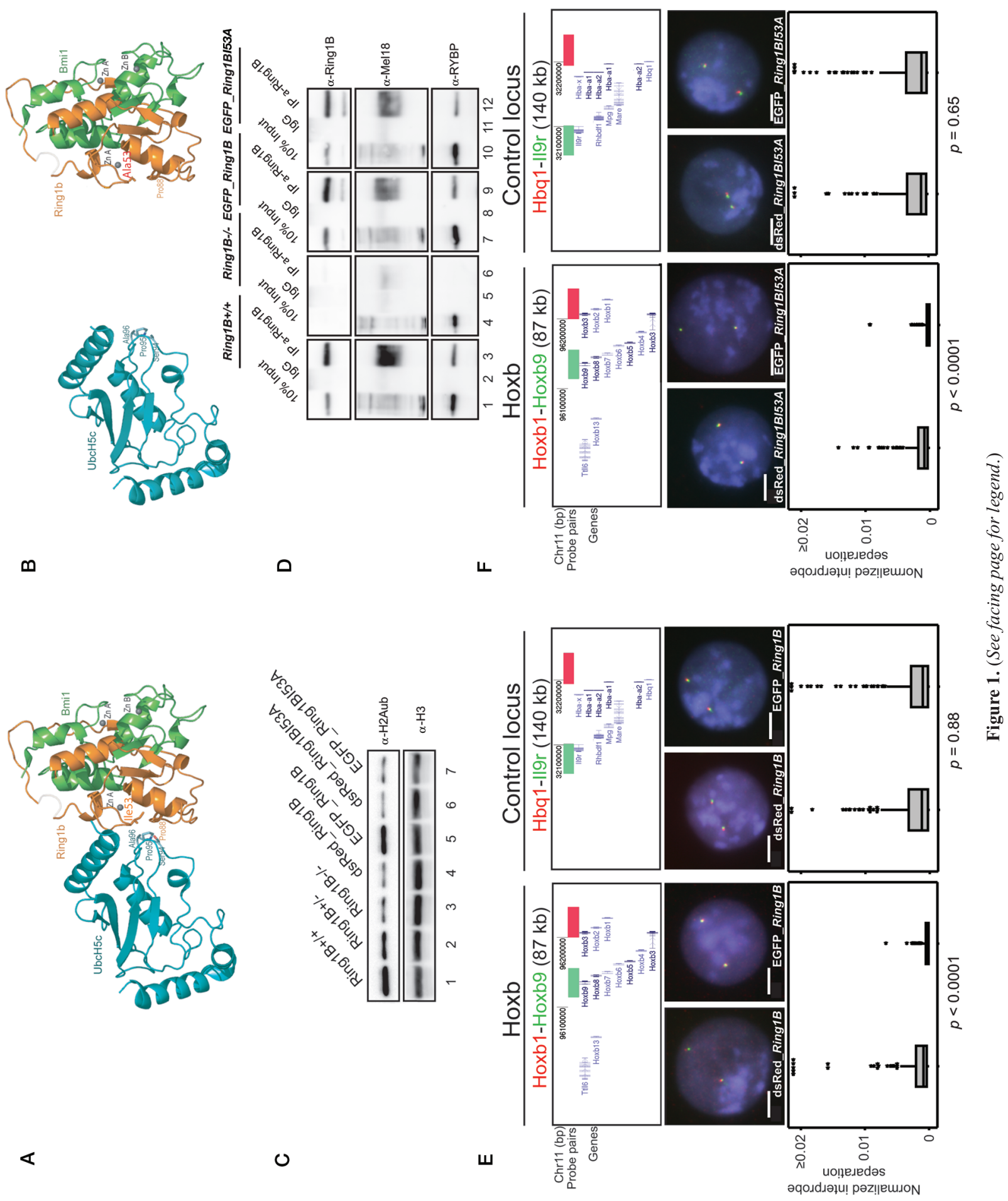




\section{PRC1-MEDIATED CHROMATIN COMPACTION AT HOX LOCI DOES NOT REQUIRE HISTONE UBIQUITINATION BY RING1B}

Ubiquitin ligase activity resides in the amino-terminal Ring domain of Ring1B, not Bmil (Buchwald et al. 2006; $\mathrm{Li}$ et al. 2006). Moreover, the E3 ligase activity of Ring1B/ Bmil or Ring1B/Mel18 critically depends on interaction with an E2 enzyme to catalyze ubiquitin transfer from the E2 to the target (Buchwald et al. 2006; Elderkin et al. 2007).

On the basis of other known E2-E3 structures, modeling of the Ring1B/Bmil heterodimer with $\mathrm{E} 2-\mathrm{UbcH} 5 \mathrm{c}$ predicts that isoleucine 53 (Ile 53) of Ring1B should be an important contact residue with the E2. Indeed, mutation of this residue (I53A) did abrogate $\mathrm{H} 2 \mathrm{~A}$ ubiquitination in vitro without affecting Ring1B/Bmil or Ring1B/Mel18 interaction (Fig. 1B) (Buchwald et al. 2006; Elderkin et al. 2007).

Consistent with these in vitro data, we found that rescue of Ring1B-null ESCs with an I53A mutant Ring1B did not restore global $\mathrm{H} 2 \mathrm{~A}$ ubiquitination (Fig. 1C) but did reestablish an apparently intact PRC1-like complex (Fig. 1D). Surprisingly, this mutant form of Ring $1 \mathrm{~B}$ was also able both to rerepress Hox gene expression (Eskeland et al. 2010) and recompact Hox chromatin structure (Fig. 1F). Hence, we concluded that the $\mathrm{H} 2 \mathrm{~A}$ ubiquitination activity of Ring1B is not required for chromatin compaction and gene silencing. Rather, we suggest that it is chromatin compaction itself that may be directly responsible for gene silencing.

\section{HISTONE ACETYLATION AND CHROMATIN COMPACTION}

So, do the findings described above eliminate histone modification from a direct role in Polycomb-mediated chromatin compaction? It has been suggested that among histone modifications, acetylation in particular can directly affect secondary chromatin structures. This could be mediated by, for example, acetylation altering nucleosome-DNA or nucleosome-nucleosome interactions and by neutralizing charge in the histone amino-terminal tails (Tse et al. 1998; Wolffe and Hayes 1999; Carruthers and Hansen 2000; Wang et al. 2001; Shogren-Knaak et al. 2006; Henikoff 2008; Robinson et al. 2008). Moreover, in mammalian cells, the inhibition of histone deacetylases (HDACs) and the consequently increased steady-state levels of histone acetylation both decrease chromatin compaction (Toth et al. 2004; Lleres et al. 2009) and increase chromatin accessibility (Gorisch et al. 2005).

\section{HISTONE DEACETYLATION LEADS TO CHROMATIN DECOMPACTION AT POLYCOMB TARGET LOCI}

Polycomb complexes have also been associated with histone deacetylation. In mammalian cells, the PRC2 component EED interacts with the HDACs 1 and 2 (van der Vlaag and Otte 1999), and HDAC2 copurifies in a PRC2 complex (Pasini et al. 2010). In addition, HDAC1 copurifies with both PRC2 (Kuzmichev et al. 2002) and PRC1 (Chang et al. 2001). In Drosophila, the HDAC RPD3 can be found in a 1MDa PRC2-like complex, is present at a Polycomb response element (PRE), and is required for Polycomb silencing (Tie et al. 2003). Likewise, the dMi-2 component of an HDAC complex also interacts genetically with Polycomb mutations (Kehle et al. 1998). HDAC complexes have been implicated in Polycomb silencing in mammalian cells: The NuRD complex facilitates Polycomb binding and H3K27 methylation in acute promyelocytic leukemia (Morey et al. 2008). Finally, the Class III (NAD ${ }^{+}$-dependent) HDAC SirT1 has been found in a PRC2-like complex in undifferentiated ESCs (Kuzmichev et al. 2005). A causal role for histone deacetylation in Polycomb-mediated silencing is evidenced by the up-regulation of $\alpha$-globin expression in human cells after treatment with HDAC inhibitors (Garrick et al. 2008).

Given the association of HDACs with Polycomb complexes, the suggested role of histone acetylation in opening chromatin structure, and the fact that the HDAC inhibitor trichostatin A (TSA) can induce basal ( fivefold) expression of a Polycomb-silenced gene in human ESCs (Garrick et al. 2008), we sought to determine whether there might be a role for histone deacetylation in PRCmediated chromatin compaction.

In a previous study, we had not seen effects of TSA on Hox chromatin compaction in ESCs (Chambeyron and Bick-

\footnotetext{
Figure 1. Mutant form of Ring1B that is unable to ubiquitinate H2AK119 rescues chromatin compaction at Hox loci. (A) Structural model of the interaction of the Ring1B/Bmil heterodimer with E2 UbcH5c. Ring1B interacts with E2 (Ser-Pro-Ala region) through isoleucine 53 (Ile 53) and proline 88 (Pro 88). (B) Isoleucine 53 to alanine (I53A) mutant form of Ring1B abrogates the interaction between Ring1B/Bmil and E2, resulting in loss of Ring1B's catalytic activity, whereas the folding of Ring1B stays intact. (C) Western blots of nuclei from wild-type (WT) $\left(\right.$ Ring $\left.1 B^{+++}\right)$, Ring1 $1 B^{+/}$, and Ring1B null (Ring1B $B^{-/}$) cells and from cells carrying transgenes for the conditional rescue of WT Ring1B or mutant I53A Ring1B, either before (dsRed) or after (EGFP) induction of Ring1B expression (Eskeland et al. 2010). (Top panel) Probed with anti-H2Aub (1:1000; E6C5; Millipore); (bottom panel) loading control anti-H3 $(1: 50,000 ; \mathrm{ab} 1791 ; \mathrm{Abcam})$. (D) Ring1B rescue proteins interact with PRC1 components. Immunoprecipitation with anti-IgG or antiRing1B (clone3-3, ABIN130656, antibodies-online) from WT (Ring1B ${ }^{+/+}$) (lanes 1-3), Ring1B ${ }^{-/-}$(lanes 4-6), EGFP WT (lanes 7-9), or Ring1BI53A (lanes 10-12) nuclear extracts. Ten percent of total protein extracts were loaded as inputs. Western blots were probed with antibodies against Ring1B, Mel18 (Santa Cruz Biotechnology), and RYBP (AB3637; Chemicon/Millipore). (E) Ring1B-null cells rescued with WT Ring1B recompact chromatin structure at Hoxb loci. FISH with probe pairs at Hoxb and a control locus on chromosome 11 in methanol-acetic acid-fixed nuclei of dsRed_RinglB (null for Ring1B expression) and EGFP_Ring1B ESCs counterstained with DAPI (blue). Bar, $5 \mu \mathrm{m}$. Above the images, the diagrams show the probe positions in the UCSC Mouse Genome Browser (Feb. 2006 assembly, mm8 build 36). Genome position is in base pairs. Below images, box plots show distribution of interprobe distances squared $\left(d^{2}\right)$ normalized for nuclear radius squared $\left(r^{2}\right)$. (Shaded boxed areas) Median and interquartile range of data; (asterisks) outliers. $n=2$ biological replicates, each of 100 loci. Statistical significance of differences was examined by Mann-Whitney U tests. $(F)$ As in $E$, but for the I53A mutant Ring1B. (A, B, Adapted, with permission, from Buchwald et al. 2006.)
} 
A

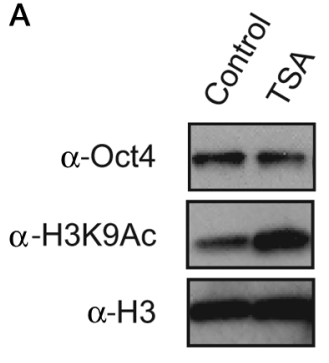

B

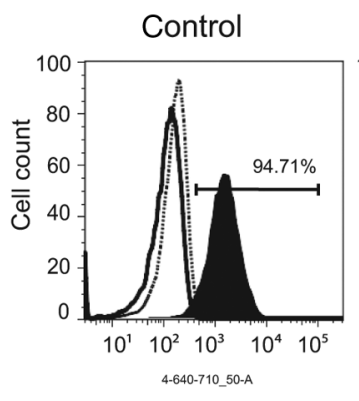

TSA

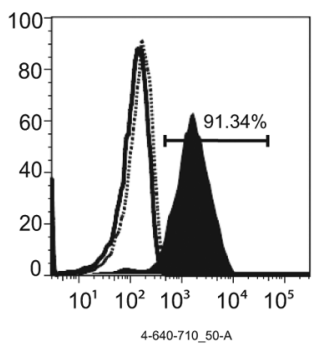

Fluorescence intensity

C

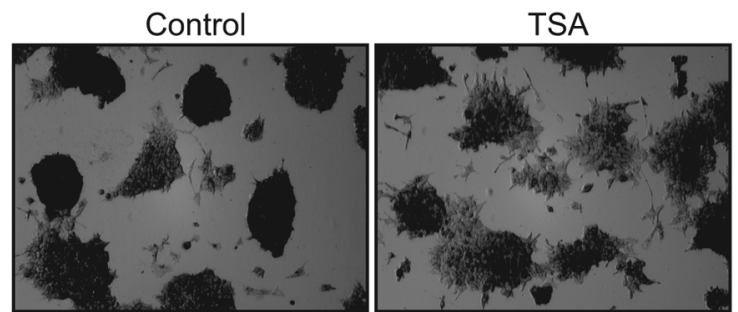

Figure 2. TSA treatment of ESCs. $(A)$ Undifferentiated OS25 ESCs were treated with DMSO (control) or 50 nM trichostatin A (TSA) for $4 \mathrm{~h}$. Western blot of nuclei was probed with antibodies against Oct4 (1:1000), H3K9Ac (1:1000), and H3. (B) Flow cytometric analysis of Oct4 levels in control versus TSA-treated ESCs. (Black line) Cells stained with secondary antibody only (1:500; Alexa Fluor 647 goat antimouse, A-21236; Invitrogen, Molecular Probes), (dotted line) cells stained with antimouse IgG1א (1:400; eBioscience 16-4714-81), (filled area) cells stained with 1:100 anti-Oct4 (611203; BD Transduction Laboratories). (C) Alkaline phosphatase staining of control and TSA-treated OS25 ESC colonies fixed in 4\% paraformaldehyde for 5 min.

more 2004), but given the current understanding of the effects of TSA on cell cycle and differentiation (Taddei et al. 2005; Karantzali et al. 2008), the concentrations of TSA used in that study (160 nM TSA for $24 \mathrm{~h}$ ) were likely too high.

Undifferentiated ESCs, grown in the presence of LIF, were seeded at $1 \times 10^{5}$ cells $/ \mathrm{mL}$, and after $3 \mathrm{~d}$ TSA (Sigma), dissolved in dimethyl sulfoxide (DMSO), was added to a final concentration of $50 \mathrm{~nm}$ and incubated for $4 \mathrm{~h}$ at $37^{\circ} \mathrm{C}$. Control cells were incubated in DMSO for the same time period. Western blotting (Fig. 2A) indicated that this treatment was sufficient to increase bulk levels of acetylated $\mathrm{H} 3 \mathrm{~K} 9$ in the ESCs without a detectable decrease in levels of Oct4. FACs sorting indicated that, indeed, $>90 \%$ of TSA-treated cells remain positive for Oct 4 (Fig. 2B) and, together with alkaline phosphatase staining of the treated ESC colonies (Fig. 2C), suggested that this short TSA treatment had not induced differentiation (Karantzali et al. 2008).

Immunoprecipitation of uncross-linked, micrococcal nuclease-digested chromatin (nChIP) in presence of $5 \mathrm{~mm}$ sodium butyrate, using a modification of previously described methods (Hebbes et al. 1988; O'Neill and Turner 2003; Eskeland et al. 2010), followed by real-time PCR analysis, showed that the TSA treatment resulted in significantly increased levels of H3k9Ac at Hox loci, and to a lesser extent at another Polycomb target locus in ESCs, Olig2 (Fig. 3A). TSA actually induces a decrease in H3K9Ac at loci that are already active and hyperacetylated in undifferentiated ESCs ( $\beta$-actin and Pou Ff1/Oct4), correlating with observations that $\mathrm{H} 3 \mathrm{ac}$ gradually decreases at the Nanog promoter during a TSA time course in ESCs (Karantzali et al. 2008). These data suggest that the overall balance, as well as the absolute levels, of histone acetylation in ESCs is altered by TSA treatment.

One trivial explanation for any effect of TSA on Polycomb target loci might have been that TSA induces acetylation of H3K27, replacing H3K27me3 and thus antagonizing PRC1 binding (Banerjee et al. 2009; Pasini et al. 2010). However, nChIP revealed that $\mathrm{H} 3 \mathrm{~K} 27 \mathrm{me} 3$ was still present at the promoters of Hox genes and Olig2 in TSA-treated ESCs (Fig. 3B), as has previously been reported for other Polycomb targets in TSA-treated human (Garrick et al. 2008) and mouse ESCs (Karantzali et al. 2008).

FISH analysis with fosmid probe pairs that span the Hoxb and Hoxd loci and a control locus (Hbq1-I19r) was used to assess the state of chromatin compaction at these loci in untreated and TSA-treated ESCs. We have used this method extensively to assess chromatin decompaction at Hox loci during differentiation and development (Chambeyron et al. 2005; Morey et al. 2007). Interprobe distances $\left(d^{2}\right)$ were normalized to nuclear radius squared $\left(r^{2}\right)$. To estimate the nuclear radius, nuclear area was measured from the total DAPI-stained area and converted to the radius of a circle of the same area $\left(\right.$ Area $\left.=\pi r^{2}\right)$. Thus, final interprobe separation is expressed as $d^{2} / r^{2}$. The statistical significance of differences in normalized mean-squared interprobe distances was assessed using the nonparametric Mann-Whitney $\mathrm{U}$ test to examine the null hypothesis that two sets of data show the same distribution.

This FISH analysis did reveal a significant decompaction at Hox loci in TSA-treated ESCs, but not at a control non-Polycomb target locus (Fig. 4). However, this decompaction was not as great (twofold less) as that seen in cells that lack PRC2 or PRC1 (Fig. 5A) (Eskeland et 


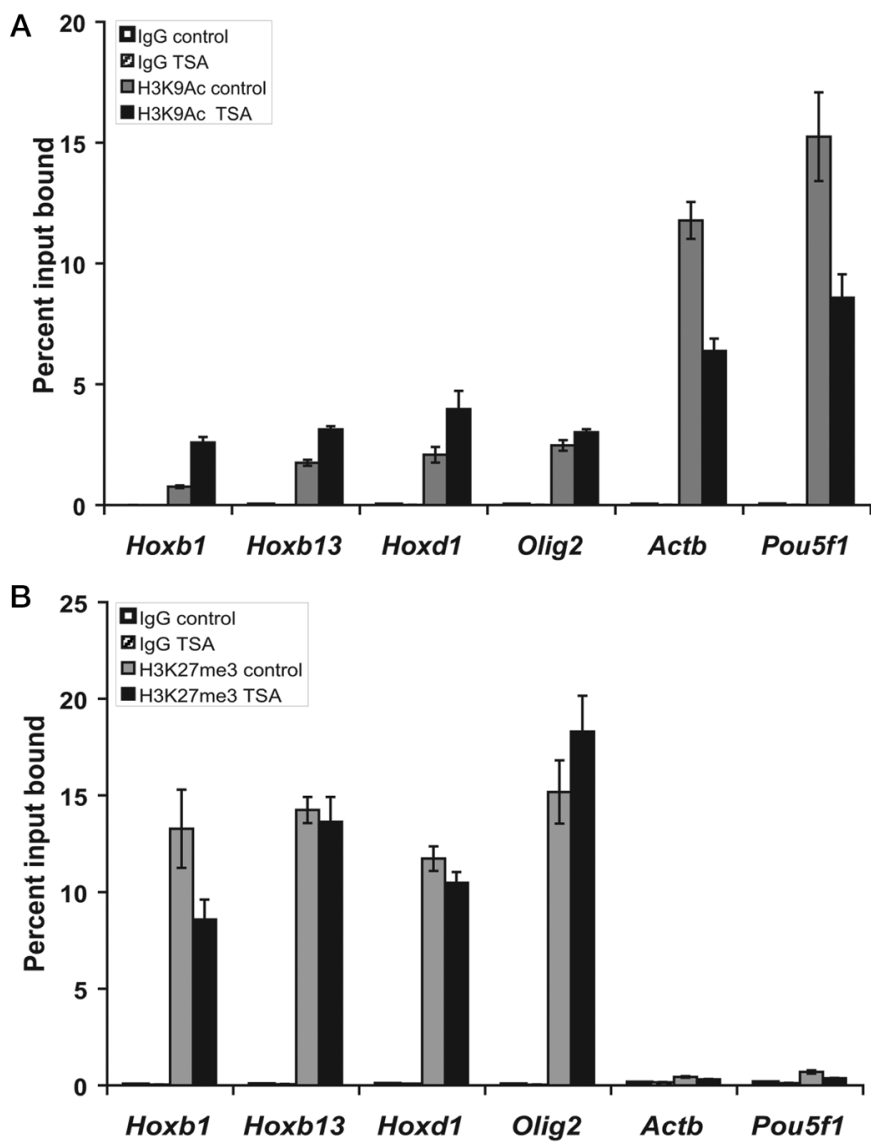

Figure 3. Chromatin immunoprecipitation demonstrates that TSA increases acetylation of H3K9 on Hox promoters. Quantitative nChIP analysis for $(A) \mathrm{H} 3 \mathrm{~K} 9 \mathrm{ac}$ (Millipore $07-352$, with $5 \mathrm{~mm}$ sodium butyrate in all buffers to inhibit further HDAC activity during sample preparation) (three biological replicates \pm S.E.M) and (B) H3K27me3 (Abcam ab6002) (two biological replicates \pm S.E.M) assayed at promoters of Hoxb1, Hoxb13, Hoxd1, Olig2, Actb ( $\beta$-actin), and Pou5f1 (Oct4) in control (gray bars) versus TSA (black bars) ( $50 \mathrm{~nm}$ for $4 \mathrm{~h}$ )-treated ESCs. IgG ChIP controls are also shown for control (white bars) and TSA (hashed bars).
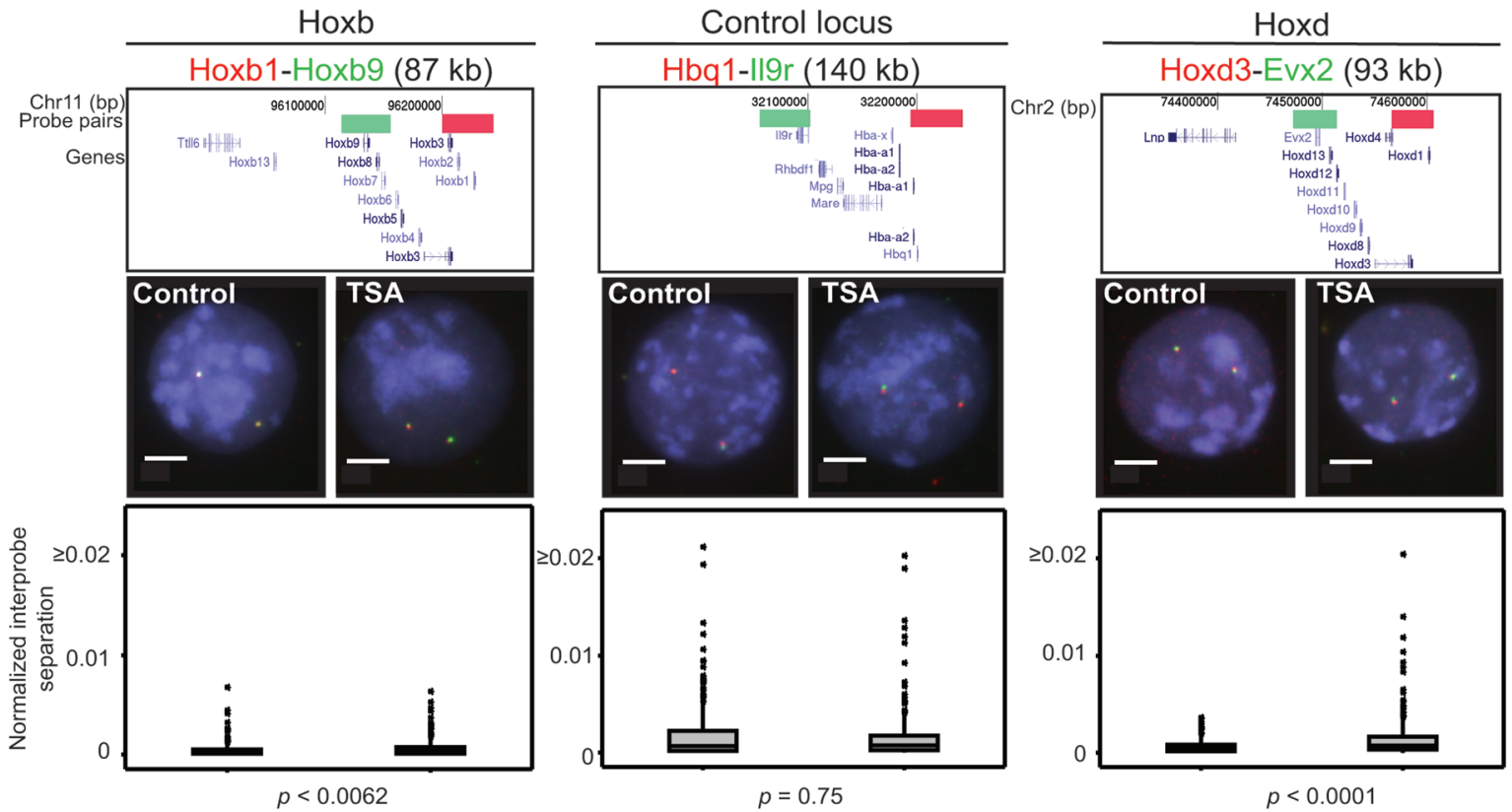

Figure 4. Chromatin decompaction is induced at Hox loci by TSA. Two-dimensional (2D) FISH with probe pairs at Hoxb, Hoxd, and a control locus in nuclei of control versus TSA ( $50 \mathrm{~nm}$ for $4 \mathrm{~h}$ )-treated OS25 ESCs counterstained with DAPI (blue). Bar, $5 \mu \mathrm{m}$. Probe position and distribution of normalized interprobe distances between control and treated cells is as in Figure 1E. $n=2 \times$ biological replicates, $n=100$ loci each. 
A
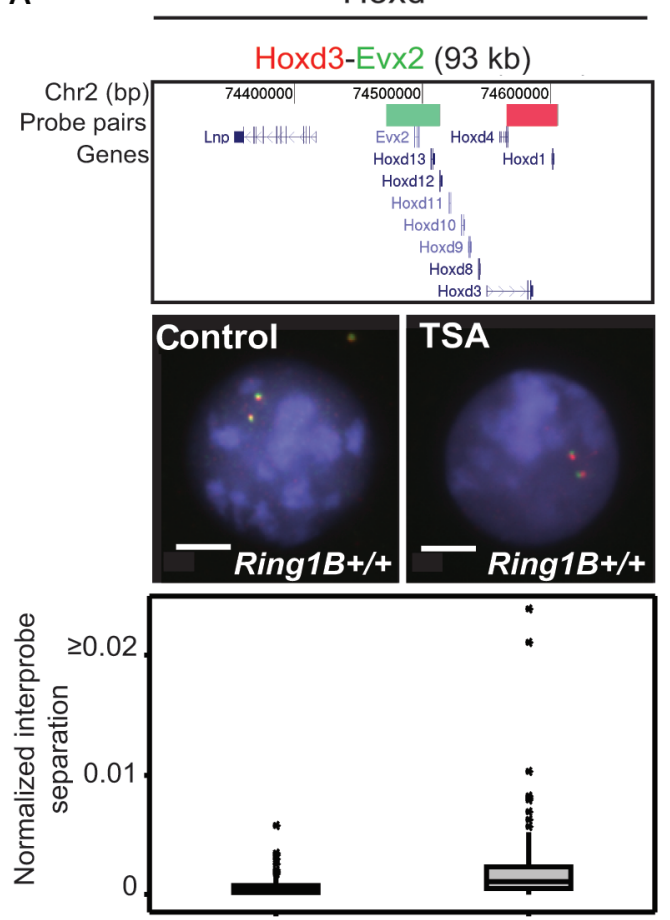

$p<0.0001$

B
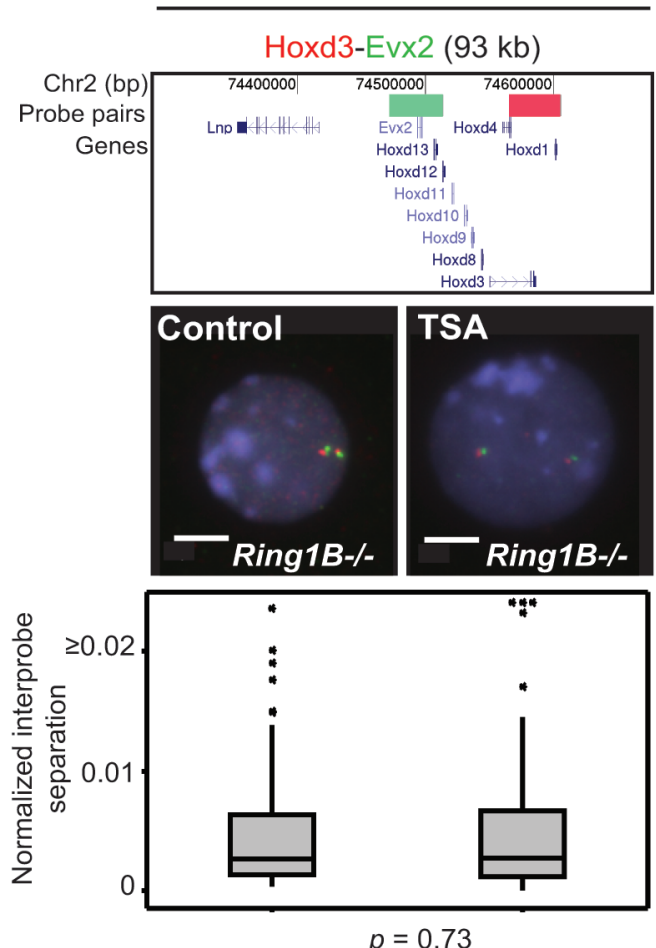

Control locus
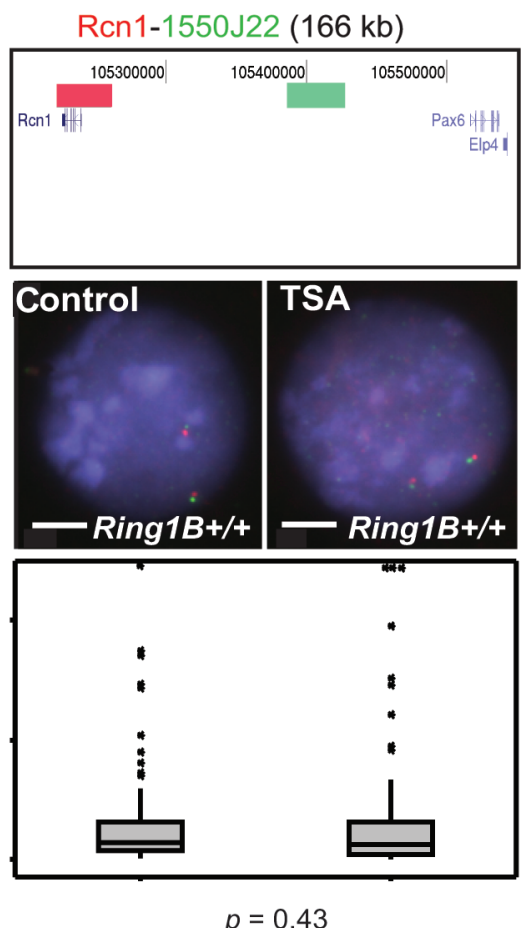

Control locus
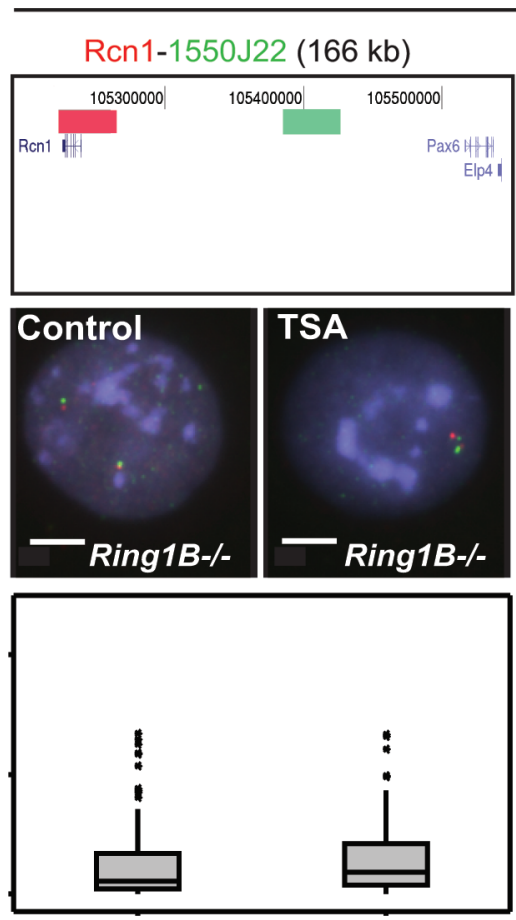

$p=0.15$

Figure 5. TSA does not affect chromatin compaction in PRC1 mutant ESCs. (A) 2D FISH with probe pairs at Hoxd and a control locus in nuclei of control versus TSA ( $50 \mathrm{~nm}$ for $4 \mathrm{~h}$ )-treated Ring $1 B^{+/+}$ESCs counterstained with DAPI (blue). Bar, $5 \mu \mathrm{m}$. Probe position and distribution of normalized interprobe distances between control and treated cells is as in Figure 1E. $n=100$ loci. $(B)$ As in $A$, but for Hoxd and a control locus in Ring $1 B^{-1-}$ ESCs. $n=100$ loci. 
al. 2010). Although at a gross cytological level TSA is known to be capable of inducing visible chromatin decondensation (Toth et al. 2004; Lleres et al. 2009), these studies were not able to ascertain whether this decompaction was global or specific to certain loci. Here we have shown that the effects of TSA on chromatin compaction are not global and that loci subject to Polycomb-mediated repression seem to be one class of loci susceptible to TSA-mediated chromatin decompaction.

\section{HISTONE DEACETYLATION IS IN POLYCOMB-MEDIATED CHROMATIN COMPACTION PATHWAY}

TSA treatment, and the consequent elevated levels of histone acetylation, may act within the Polycomb pathway itself or through a parallel one. In the latter case, TSA treatment of PRC mutant cells might lead to even further levels of chromatin decompaction above and beyond those seen in the mutant cells alone. In the former case, TSA treatment of Polycomb mutant cells might not give any additive effect.

To determine whether chromatin decompaction mediated by TSA treatment or by loss of Ring1B is synergistic or redundant, we analyzed chromatin compaction at Hox loci in feeder-dependent wild-type (WT) $\left(\right.$ Ring $\left.1 B^{+/+}\right)$and Ring1B-null (Ring1B ${ }^{-/}$) cells (Leeb and Wutz 2007; Eskeland et al. 2010), and these same cells treated with 50 nM TSA for $3 \mathrm{~h}$ with an additional hour of fibroblast reattachment in the presence of TSA to separate the ESCs from the feeders (i.e., total of $4 \mathrm{~h}$ of TSA treatment).

As seen with OS25 ESCs (Fig. 4), TSA treatment decompacts chromatin at Hoxd in the parental WT $\left(\right.$ Ring $\left.1 B^{+/+}\right)$ESCs (Fig. 5A), but it had no further effect on the already decompacted Hox loci in Ring $1 B^{-/}$cells (Fig. $5 \mathrm{~B})$. This is consistent with the effects of PRC1 and histone deacetylation being in the same pathway of chromatin compaction.

\section{MECHANISMS OF TRANSCRIPTIONAL REPRESSION BY HISTONE DEACETYLATION AND POLYCOMB}

The presence of transcription initiation factors and RNAPII at the promoters of inactive Hox genes and at a Polycomb repressed reporter in Drosophila (Breiling et al. 2001; Dellino et al. 2004) suggests that PRC1 inhibits steps downstream from RNAPII binding itself, such as promoter opening or transcriptional elongation (Zhou et al. 2008). Indeed, a form of RNA polymerase II, detected by antibodies that recognize the serine 5 phosphorylated form (RNAPII Ser5P), is found at Hox genes in ESCs, and Ring1B is necessary to prevent this RNAPII from proceeding to productive transcriptional elongation (Stock et al. 2007). Therefore, the challenge is to understand how PRC1-mediated physical compaction and histone hypoacetylation might act to block transcriptional elongation or, alternatively, to favor early termination (Buratowski 2009).

In vitro, one PRC1-like complex can compact three nucleosomes (Francis et al. 2004) and thus could act as a bridge chromatin fibers. Alternatively, PRC1 binding to nu- cleosomes might act to block nucleosome mobility, and, indeed, PRCs do block chromatin remodeling in vitro (Francis et al. 2001). Exciting new evidence provides support for a role of Polycomb in regulating nucleosome stability in vivo (Deal et al. 2010) with nucleosomes at Polycomb-silenced regions in Drosophila tissue culture cells having a longer lifetime at these loci $(1.5 \mathrm{~h})$ than do nucleosomes at active genes. The hypoacetylation of histone tails, particularly those on the (H3-H4) tetramer, might also similarly act to further increase nucleosome stability (Henikoff 2008). We suggest that together, PRC1 binding and histone hypoacetylation create a chromatin template in which nucleosomes are rather stably bound and thus disfavors productive elongation of mRNAs by RNAPII.

\section{ACKNOWLEDGMENTS}

This work was supported by the Medical Research Council, UK.

\section{REFERENCES}

AzuaraV, Perry P, Sauer S, Spivakov M, Jorgensen HF, John RM, Gouti M, Casanova M, Warnes G, Merkenschlager M, Fisher AG. 2006. Chromatin signatures of pluripotent cell lines. Nat Cell Biol 8: 532-538.

Banerjee TF, Stratton CA, Prasad-Sinha J, Stepanik V, Zlobin A, Diaz MO, Scacheri PC, Harte PJ. 2009. CBP-mediated acetylation of histone $\mathrm{H} 3$ lysine 27 antagonizes Drosophila Polycomb silencing. Development 136: 3131-3141.

Bernstein BE, Mikkelsen TS, Xie X, Kamal M, Huebert DJ, Cuff J, Fry B, Meissner A, Wernig M, Plath K, et al. 2006. A bivalent chromatin structure marks key developmental genes in embryonic stem cells. Cell 125: 315-326.

Boyer LA, Plath K, Zeitlinger J, Brambrink T, Medeiros LA, Lee TI, Levine SS, Wernig M, Tajonar A, Ray MK, et al. 2006. Polycomb complexes repress developmental regulators in murine embryonic stem cells. Nature 441: 349-353.

Breiling A, Turner BM, Bianchi ME, Orlando V. 2001. General transcription factors bind promoters repressed by Polycomb group proteins. Nature 412: 651-655.

Buchwald G, van der Stoop P, Weichenrieder O, Perrakis A, van Lohuizen M, Sixma TK. 2006. Structure and E3-ligase activity of the Ring-Ring complex of Polycomb proteins Bmil and Ring1b. EMBO J 25: 2465-2474.

Buratowski S. 2009. Progression through the RNA polymerase II CTD cycle. Mol Cell 36: 541-546.

Carruthers LM, Hansen JC. 2000. The core histone N termini function independently of linker histones during chromatin condensation. J Biol Chem 275: 37285-37290.

Chambeyron S, Bickmore WA. 2004. Chromatin decondensation and nuclear reorganization of the HoxB locus upon induction of transcription. Genes Dev 18: 1119-1130.

Chambeyron S, Da Silva NR, Lawson KA, Bickmore WA. 2005. Nuclear re-organisation of the Hoxb complex during mouse embryonic development. Development 132: 2215-2223.

Chang YL, Peng YH, Pan IC, Sun DS, King B, Huang DH. 2001. Essential role of Drosophila Hdac1 in homeotic gene silencing. Proc Natl Acad Sci 98: 9730-9735.

Deal RB, Henikoff JG, Henikoff S. 2010. Genome-wide kinetics of nucleosome turnover determined by metabolic labeling of histones. Science 328: 1161-1164.

Dellino GI, Schwartz YB, Farkas G, McCabe D, Elgin SC, Pirrotta V. 2004. Polycomb silencing blocks transcription initiation. Mol Cell 13: 887-893.

de Napoles M, Mermoud JE, Wakao R, Tang YA, Endoh M, Appanah R, Nesterova TB, Silva J, Otte AP, Vidal M, et al. 2004. Polycomb group proteins Ring1A/B link ubiquitylation of histone $\mathrm{H} 2 \mathrm{~A}$ to heritable gene silencing and $\mathrm{X}$ inactivation. Dev 
Cell 7: 663-676.

Elderkin S, Maertens GN, Endoh M, Mallery DL, Morrice N, Koseki H, Peters G, Brockdorff N, Hiom K. 2007. A phosphorylated form of Mel-18 targets the Ring1B histone H2A ubiquitin ligase to chromatin. Mol Cell 28: 107-120.

Endoh M, Endo TA, Endoh T, Fujimura Y, Ohara O, Toyoda T, Otte AP, Okano M, Brockdorff N, Vidal M, Koseki H. 2008. Polycomb group proteins Ring1A/B are functionally linked to the core transcriptional regulatory circuitry to maintain ES cell identity. Development 135: 1513-1524.

Eskeland R, Leeb M, Grimes GR, Kress C, Boyle S, Sproul D, Gilbert N, Fan Y, Skoultchi AI, Wutz A, Bickmore WA. 2010. Ring1B compacts chromatin structure and represses gene expression independent of histone ubiquitination. Mol Cell 38: 452-464.

Francis NJ, Saurin AJ, Shao Z, Kingston RE. 2001. Reconstitution of a functional core Polycomb repressive complex. Mol Cell 8: 545-556.

Francis NJ, Kingston RE, Woodcock CL. 2004. Chromatin compaction by a Polycomb group protein complex. Science 306: 1574-1577.

Garrick D, De Gobbi M, Samara V, Rugless M, Holland M, Ayyub H, Lower K, Sloane-Stanley J, Gray N, Koch C, et al. 2008. The role of the Polycomb complex in silencing $\alpha$-globin gene expression in nonerythroid cells. Blood 112: 3889-3899.

Gorisch SM, Wachsmuth M, Toth KF, Lichter P, Rippe K. 2005. Histone acetylation increases chromatin accessibility. J Cell Sci 118: 5825-5834.

Hebbes TR, Thorne AW, Crane-Robinson C. 1988. A direct link between core histone acetylation and transcriptionally active chromatin. EMBO J 7: 1395-1402.

Henikoff S. 2008. Nucleosome destabilization in the epigenetic regulation of gene expression. Nat Rev Genet 9: 15-26.

Jorgensen HF, Giadrossi S, Casanova M, Endoh M, Koseki H, Brockdorff N, Fisher AG. 2006. Stem cells primed for action: Polycomb repressive complexes restrain the expression of lineage-specific regulators in embryonic stem cells. Cell Cycle 5: 1411-1414.

Karantzali E, Schulz H, Hummel O, Hubner N, Hatzopoulos A, Kretsovali A. 2008. Histone deacetylase inhibition accelerates the early events of stem cell differentiation: Transcriptomic and epigenetic analysis. Genome Biol 9: R65. doi: 10.1186/gb-20089-4-r65.

Kehle J, Beuchle D, Treuheit S, Christen B, Kennison JA, Bienz M, Muller J. 1998. dMi-2, a hunchback-interacting protein that functions in Polycomb repression. Science 282: 1897-1900.

$\mathrm{Ku}$ M, Koche RP, Rheinbay E, Mendenhall EM, Endoh M, Mikkelsen TS, Presser A, Nusbaum C, Xie X, Chi AS, et al. 2008. Genomewide analysis of PRC1 and PRC2 occupancy identifies two classes of bivalent domains. PLoS Genet 4: e1000242. doi: 10.1371/journal.pgen.1000242.

Kuzmichev A, Nishioka K, Erdjument-Bromage H, Tempst P, Reinberg D. 2002. Histone methyltransferase activity associated with a human multiprotein complex containing the Enhancer of Zeste protein. Genes Dev 16: 2893-2905.

Kuzmichev A, Margueron R, Vaquero A, Preissner TS, Scher M, Kirmizis A, Ouyang X, Brockdorff N, Bate-Shen C, Farnham P, Reinberg D. 2005. Composition and histone substrates of Polycomb repressive group complexes change during cellular differentiation. Proc Natl Acad Sci 102: 1859-1864.

Lee TI, Jenner RG, Boyer LA, Guenther MG, Levine SS, Kumar RM, Chevalier B, Johnstone SE, Cole MF, Isono K, et al. 2006. Control of developmental regulators by Polycomb in human embryonic stem cells. Cell 125: 301-313.

Leeb M, Wutz A. 2007. Ring1B is crucial for the regulation of developmental control genes and PRC1 proteins but not $\mathrm{X}$ inactivation in embryonic cells. J Cell Biol 178: 219-229.

Li Z, Cao R, Wang M, Myers MP, Zhang Y, Xu RM. 2006. Structure of a Bmi-1-Ring1B Polycomb group ubiquitin ligase complex. J Biol Chem 281: 20643-20649.

Lleres D, James J, Swift S, Norman DG, Lamond AI. 2009. Quantitative analysis of chromatin compaction in living cells using FLIM-FRET. J Cell Biol 187: 481-496.

Lu X, Simon MD, Chodaparambil JV, Hansen JC, Shokat KM,
Luger K. 2008. The effect of H3K79 dimethylation and H4K20 trimethylation on nucleosome and chromatin structure. Nat Struct Mol Biol 15: 1122-1124.

Margueron R, Li G, Sarma K, Blais A, Zavadil J, Woodcock CL, Dynlacht BD, Reinberg D. 2008. Ezh1 and Ezh2 maintain repressive chromatin through different mechanisms. Mol Cell 32: 503-518.

Morey C, Da Silva NR, Perry P, Bickmore WA. 2007. Nuclear reorganisation and chromatin decondensation are conserved, but distinct, mechanisms linked to Hox gene activation. Development 134: 909-919.

Morey L, Brenner C, Fazi F, Villa R, Gutierrez A, Buschbeck M, Nervi C, Minucci S, Fuks F, Di Croce L. 2008. MBD3, a component of the NuRD complex, facilitates chromatin alteration and deposition of epigenetic marks. Mol Cell Biol 28: 5912-5923.

O'Neill LP, Turner BM. 2003. Immunoprecipitation of native chromatin: NChIP. Methods 31: 76-82.

Pasini D, Malatesta M, Jung HR, Walfridsson J, Willer A, Olsson L, Skotte J, Wutz A, Porse B, Jensen ON, Helin K. 2010. Characterization of an antagonistic switch between histone $\mathrm{H} 3$ lysine 27 methylation and acetylation in the transcriptional regulation of Polycomb group target genes. Nucleic Acids Res 38: 49584969.

Robinson PJ, An W, Routh A, Martino F, Chapman L, Roeder RG, Rhodes D. $2008.30 \mathrm{~nm}$ chromatin fibre decompaction requires both H4-K16 acetylation and linker histone eviction. $J$ Mol Biol 381: 816-825.

Shogren-Knaak M, Ishii H, Sun JM, Pazin MJ, Davie JR, Peterson CL. 2006. Histone H4-K16 acetylation controls chromatin structure and protein interactions. Science 311: 844-847.

Simon JA, Kingston RE. 2009. Mechanisms of Polycomb gene silencing: Knowns and unknowns. Nat Rev Mol Cell Biol 10: 697-708.

Stock JK, Giadrossi S, Casanova M, Brookes E, Vidal M, Koseki H, Brockdorff N, Fisher AG, Pombo A. 2007. Ring1-mediated ubiquitination of $\mathrm{H} 2 \mathrm{~A}$ restrains poised RNA polymerase II at bivalent genes in mouse ES cells. Nat Cell Biol 9: 1428-1435.

Taddei A, Roche D, Bickmore WA, Almouzni G. 2005. The effects of histone deacetylase inhibitors on heterochromatin: Implications for anticancer therapy? EMBO Rep 6: 520-524.

Terranova R, Yokobayashi S, Stadler MB, Otte AP, van Lohuizen M, Orkin SH, Peters AH. 2008. Polycomb group proteins Ezh2 and Rnf2 direct genomic contraction and imprinted repression in early mouse embryos. Dev Cell 15: 668-679.

Tie F, Prasad-Sinha J, Birve A, Rasmuson-Lestander A, Harte PJ. 2003. A 1-megadalton ESC/E(Z) complex from Drosophila that contains polycomblike and RPD3. Mol Cell Biol 23: 33523362.

Toth KF, Knoch TA, Wachsmuth M, Frank-Stohr M, Stohr M, Bacher CP, Muller G, Rippe K. 2004. Trichostatin A-induced histone acetylation causes decondensation of interphase chromatin. J Cell Sci 117: 4277-4287.

Tse C, Sera T, Wolffe AP, Hansen JC. 1998. Disruption of higherorder folding by core histone acetylation dramatically enhances transcription of nucleosomal arrays by RNA polymerase III. Mol Cell Biol 18: 4629-4638.

van der Vlaag J, Otte AP. 1999. Transcriptional repression mediated by the human Polycomb-group protein EED involves histone deacetylation. Nat Genet 23: 474-478.

Wang X, He C, Moore SC, Ausio J. 2001. Effects of histone acetylation on the solubility and folding of the chromatin fiber. J Biol Chem 276: 12764-12768.

Wang H, Wang L, Erdjument-Bromage H, Vidal M, Tempst P, Jones RS, Zhang Y. 2004a. Role of histone H2A ubiquitination in Polycomb silencing. Nature 431: 873-878.

Wang L, Brown JL, Cao R, Zhang Y, Kassis JA, Jones RS. 2004 b. Hierarchical recruitment of Polycomb group silencing complexes. Mol Cell 14: 637-646.

Wolffe AP, Hayes JJ. 1999. Chromatin disruption and modification. Nucleic Acids Res 27: 711-720.

Zhou W, Zhu P, Wang J, Pascual G, Ohgi KA, Lozach J, Glass CK, Rosenfeld MG. 2008. Histone H2A monoubiquitination represses transcription by inhibiting RNA polymerase II transcriptional elongation. Mol Cell 29: 69-80. 


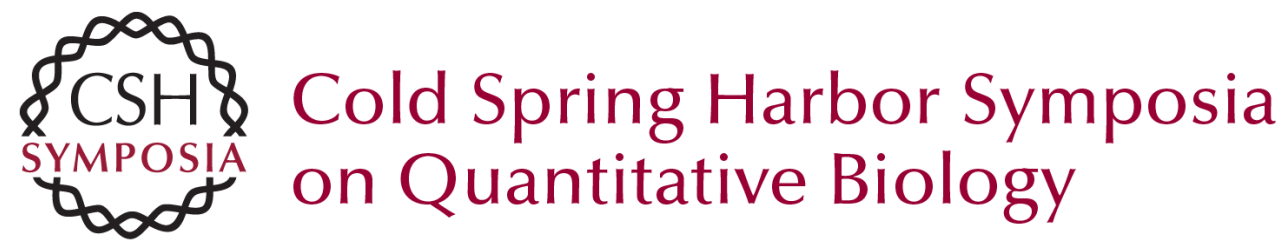

\section{Histone Acetylation and the Maintenance of Chromatin Compaction by Polycomb Repressive Complexes}

R. Eskeland, E. Freyer, M. Leeb, et al.

Cold Spring Harb Symp Quant Biol 2010 75: 71-78 originally published online April 18, 2011 Access the most recent version at doi:10.1101/sqb.2010.75.053

References This article cites 54 articles, 24 of which can be accessed free at: http://symposium.cshlp.org/content/75/71.full.html\#ref-list-1

License

Email Alerting Receive free email alerts when new articles cite this article - sign up in Service the box at the top right corner of the article or click here. 